Man and Nature

L'homme et la nature

\title{
English Literature as Reflected in German Literature of the Eighteenth Century
}

\section{Peter Michelsen}

Volume 9, 1990

URI : https://id.erudit.org/iderudit/1012612ar

DOI : https://doi.org/10.7202/1012612ar

Aller au sommaire du numéro

Éditeur(s)

Canadian Society for Eighteenth-Century Studies / Société canadienne d'étude du dix-huitième siècle

ISSN

0824-3298 (imprimé)

1927-8810 (numérique)

Découvrir la revue

Citer cet article

Michelsen, P. (1990). English Literature as Reflected in German Literature of the Eighteenth Century. Man and Nature / L'homme et la nature, 9, 91-108. https://doi.org/10.7202/1012612ar

Copyright (c) Canadian Society for Eighteenth-Century Studies / Sociéte canadienne d'étude du dix-huitième siècle, 1990
Ce document est protégé par la loi sur le droit d'auteur. L'utilisation des services d'Érudit (y compris la reproduction) est assujettie à sa politique d'utilisation que vous pouvez consulter en ligne.

https://apropos.erudit.org/fr/usagers/politique-dutilisation/ 


\section{English Literature as Reflected in German Literature of the Eighteenth Century ${ }^{1}$}

It may seem self-evident that the term 'German literature' implies literature written in the German language. But it was not until the seventeenth century that the dominance of Latin began to wane and the first major steps were taken by scholars and literati to validate German as a literary language. The concern with validating the language, with developing a linguistic self-consciousness, in fact continued into the eighteenth century. It was not until this time that German writers, in comparing themselves with foreign writers, began to evaluate their own self-worth. As a result, the relationship between German literature and other European literatures became more complex and was determined or accompanied by variable but definite programmatic ideas. Daniel Georg Morhof's Unterricht von der Teutschen Sprache und Poesie (Instruction in German Language and Poesey) of 1682 is a prime example, since the most important section - that on literary history - begins with fairly detailed descriptions of foreign literatures - French, Italian, English, etc. At the outset, German literary history is conceived of as comparative. To my knowledge, this is the first time in a German work that English literature appears as a unit, although for Morhof, all told, it ultimately plays only a subordinate role. Yet all this changes by the first decades of the new century: a new development is underway.

By 1739 a well-known admirer could write to the Swiss critic Johann Jakob Bodmer: 'It seems as if the English will soon be chasing the French out of Germany. It may well come to pass, as long as that blind reverence which all our courtiers and fine gentlemen bestow on the French does not creep in. ${ }^{2}$ This clear-sighted diagnosis comes from none other than Gottsched, the important German critic, who is usually seen as a staunch defender of French classicism; and it is interesting to note that English literature is played off here against French literature. This contrast between English and French was in future to be couched in much more trenchant terms: as if it were not only a matter of obvious differences in the two national characters, but of two mutually antagonistic, conflicting factors, totally different in nature. This contrast became a commonplace 
that spread throughout Germany during the eighteenth century. At the bottom of this strange and tenacious prejudice are probably not so much literary and aesthetic values as political ideas fostered by the Glorious Revolution of 1688. Interestingly enough, it is in French writings that these political ideas are first attached to national characteristics. In any event, they are already evident in the Lettres sur les Anglais et les Français written in 1694, in which the Swiss Beat Ludwig Muralt recorded his travels in England and France. In Germany, Gottsched, in the preface to his play Der Sterbende Cato (Dying Cato), referred to the inclination of the English nation to be free' and 'their almost inborn abhorrence of a tyrannical regime. ${ }^{3}$ Friedrich von Hagedorn, in one of his 'Moralische Gedichte' ('Moral Poems'), praised the British nation for just this reason: he extols the idea of English freedom and says that those who know freedom only by name are but half-happy slaves. ${ }^{4}$ Lessing, similarly, compared the 'free Englishman' with the 'Frenchman, born to serve, ${ }^{, 5}$ and the young Schiller thinks of the British as a 'free-born people. ${ }^{\prime 6}$ Friedrich Nicolai goes so far as to see the principle of political freedom as the direct cause of an aesthetics which does not tolerate rules. He states: ' $\mathrm{He}$ (the Englishman) extends Britannic freedom even to the rules of dramatic art and propriety. ${ }^{7}$ If we extend the idea of freedom, expressed in these quotations in political or social terms, and think of it as a disengagement, a loosening, a self-liberation from the constraints of authorities, conventions, rules or regulations, then we may say generally that this idea, mutatis mutandis, sponsored the reception of English literature in Germany.

Let us return to the passage in Gottsched's letter of 1739 and examine the elements of German literary life on which Gottsched based his impression that the influence of English literature was soon to predominate in Germany. Basically, he probably had two things in mind: first, the so-called 'moral weeklies' based on English models which had been the rage in Germany since 1713; and second, Bodmer's translation of Milton's Paradise Lost, published in 1732.

German libraries today still have over a hundred titles of moral weeklies dating from the years up to the $1780 \mathrm{~s},{ }^{8}$ and German contemporaries were fully aware that the genre originated in England. ${ }^{9}$ Die Discourse der Mahlern (Discourses of the Painters) by Bodmer and Breitinger of 1721 begins with a dedication 'to the illustrious spectator of the English nation' - that is to say, Addison and Steele's Spectator, and they assure the reader that they 'seek no greater honour than the knowledge that we cannot take a more excellent original as the object of our imitation. $^{10}$

The question now is what made this literary phenomenon so important, and how did it mould the taste of the German public accordingly? 
The answer, in short, is first, that the size of German readership was growing. Moral weeklies appealed not only to the scholar, but also to the man from the upper-middle class (and the woman, of course - the problems of gentlewomen are addressed very frequently) - and second, that German readers were educated not only to use their understanding, their common-sense, in dealing with problems concerning themselves, but also to be critical - even if moderately so. The impact of this literary mass-phenomenon should not be underestimated.

When Bodmer was translating Milton's epic poem in the 1720s, he sparked a fundamental controversy with far-reaching consequences. Gottsched had indeed initially approved of Milton and his German translator with some enthusiasm, ${ }^{11}$ but then, from 1740 on, he directed increasingly vehement polemic against the Swiss and their adoration of Milton. What was this literary controversy all about - this controversy that dominated German literary life in the 1740 s and was perceived by the German public more and more as a 'collision of French and English influence? ${ }^{12}$ If we attempt to extract the basic issue from the chaotic mass of mutual invective flying between Leipzig and Zurich - that is to say, the basic issue that was essential to the development of literature - it is probably to be found in Gottsched's statement on Milton's 'unregulated power of imagination. ${ }^{13}$

Although the two parties did not substantially disagree in their basic theories of art, in practice - and this was ultimately the deciding factor - they went different ways. On the one hand, Gottsched felt constrained to denounce Milton as an example of the erroneous direction art had taken in its late-Baroque unnaturalness. On the other hand, Bodmer believed that Milton led his readers 'as if unto a new Creation ${ }^{14}$ precisely by means of that power of imagination which Gottsched had condemned in Milton as far too unrestrained and improbable. At the same time, it was not so much the subject matter or the content (the use of the fantastic, for example), as the treatment of language in Bodmer's translation that was something new and that continued to have wide-ranging effect. In what Gottsched called that 'strange and repugnant nature of German expression which is otherwise considered outrageous in all our books, ${ }^{15}$ Bodmer, as he expressly states, turned to Milton himself and his 'emphatic, succinct and exalted style. ${ }^{16}$ This 'heart-moving style ${ }^{\prime 17}$ with its characteristic 'elevation of language' and 'energy' inspired Klopstock, whose reading of Bodmer's Milton had caused the 'fire that Homer had ignited in him (to flare up) into a flame, ${ }^{18}$ as he puts it, and stimulated him to write his Messias (Messiah). Klopstock's handling of the German language - turning the syntax inside out and forcing out obscurities - brought about a truly unprecedented change in the literary landscape. 
Incidentally, Paradise Lost offended not only Gottsched, but also his contemporaries for another reason which should at least be mentioned. The fact that the hero was Satan and that his heroic deed, in Gottsched's words, consisted in 'taking vengeance on the Almighty and succeeding, in spite of all resistance' was thought to be a 'terrible idea. ${ }^{19}$ In a Christian light this is indeed suspicious and apt to arouse heretical thoughts. Readings of Milton were later to produce effects that neither the author, nor the Swiss, nor Klopstock could ever have dreamed of. Blake and Shelley attest to these effects, as does Schiller in Germany: in the Räuber (The Robbers), in a passage Schiller in fact suppressed, Karl Moor asks Spielberg: 'I don't know, Moritz, if you have read Milton that man who could not tolerate anyone above him and who dared to challenge the Almighty - was he not an extraordinary genius? ${ }^{20}$ There is no doubt that the association of the rebel figure with the concept of genius is not a coincidence.

The public literary controversy concerning Milton that had been going on for years, caused the dams to burst in the middle of the century, and allowed an unchecked flow of English literature into Germany. In addition, there was, as it happened, an unforseeable development in England itself that caused a flood of books to inundate Germany from the forties on. The major part of the flood consisted of a genre which was still not really taken seriously by art critics, and which was not infrequently reviled as extravagant and flighty: the novel. In Richardson, Fielding, Smollett, Sterne and Goldsmith, there was nothing to compare with the triumph of the eighteenth-century English novel. It is perhaps possible to get a rough idea of the breathless reception of English novelists in eighteenth-century Germany if one remembers that as soon as their works first appeared in England, they were almost immediately translated into German. ${ }^{21}$ This continued for three or four decades.

As a result of the extraordinary success of this new art of the novel, the reputation of the genre slowly began to improve. This is very definitely connected to attempts by the authors to produce natural representations that were intended to give accurate descriptions of modes of human behaviour and their psychological motivation. And when Samuel Richardson combined this new form of representation with the suffering and praise of virtue, the hearts of all his readers especially his female readers - flew to him; and everyone joined Klopstock in mourning the dead Clarissa:

Doch ein Sturmwind wird (o, er kommt! entflieh du, Eh er daherrauscht) 
Grausam, indem Du nun am Hellsten glänzest,

Dich hinstürzen; allein auch hingestürzet,

Wirst Du schön sein, werden wir Dich bewundern

Aber durch Thränen!

Reizend noch stets, noch immer liebenswürdig,

Lag Clarissa, da sie uns weggeblüht war

Und noch stille Röthe die Hingesunkne

Wange bedeckte;

Freudiger war entronnen ihre Seele,

War zu Seelen gekommen, welch' ihr glichen,

Schönen, ihr verwandten, geliebten Seelen,

Die sie empfingen,

Dass in dem Himmel sanft die liedervollen,

Frohen Hügel umher zugleich ertönten:

'Ruhe Dir und Kronen des Siegs, o Seele,

Weil Du so schön warst! ${ }^{22}$

In face of the suffering and dying 'schöne Seele' (the beauteous soul), tumultuous enthusiasm swollen by torrents of tears swept through German lands. Gellert certainly spoke for most of the educated classes when he praised Richardson by considering his works to be 'nature, taste and religion.' He continues: 'Immortal is Homer, more immortal (sic) for Christians/ Is the Briton Richardson. ${ }^{23}$ The comparison with Homer shows that the novel was increasingly becoming a substitute for, if not the equivalent of, the epic. The subject of the novel is no longer the vanquishing or foundering hero, battling the dangers of the world, but man confronted by dangers from his inner being. Richardson, using his particular blend of astute edification and subtle eroticism, creates his own version of the ancient theme of 'innocence defiled' which was extraordinarily attractive to German literature. In this way, Richardson becomes the sponsor of almost 200 German novels, ${ }^{24}$ and he also propagates the middle-class tragedy to no small degree. In Lessing's Miss Sara Sampson the spirit of Richardson can be felt much more strongly than that of Lillo and his London Merchant. At the same time, the seducer, whom Richardson had still clearly endowed with traits of the Miltonic Satan, becomes more and more noticeably torn by the conflict within his own breast; until Goethe's Fernando in Stella and his Faust in the Gretchen tragedy appear as but 'seduced seducers. ${ }^{.25}$

Later, Richardson was played off against Fielding, who was said to show his characters as developing, and Friedrich von Blanckenburg was 
inspired by reflections in the introductory chapters of Tom Jones when formulating most of the theories for his Versuch über den Roman (Essay on the Novel) of 1774. Many German novelists addressed the Richardson/Fielding conflict ${ }^{26}$ in those years, and it was settled by Wieland in his Agathon in favour of Fielding. As a result, the German novel, following Fielding's model, attempted to shift away from the ideal of the 'perfect' hero and represent real characters from all social classes. Yet it was realized again and again that it was rather difficult to do this in Germany. The Literaturbriefe (Literary Letters) of 1764 wonder if it was at all possible to have a 'German Fielding who could portray the manners of the Germans as accurately as Fielding had done for the English', and they come to a very sceptical conclusion; the Germans lacked experience of the world. 'Without the knowledge of the world and without knowledge of their nation ... they soon find themselves in an arid dessert when it comes to planning the plot of a novel.' The author then gives a description of someone preparing to write a novel in the manner of Fielding:

A novel sells well; the publisher accepts it with pleasure; such a Thomas Jones is a droll thing that you can write down quickly in your leisure time. You put pen to paper, describe those short school days, whose pranks everyone remembers so fondly; the hero attends university, falls in love, God knows with whom, and now, well now you get stuck! The poor author wracks his brains. What is supposed to happen next? ... He tortures himself in vain. Finally, in despair, he flings down his pen and, crushed by this failure of his work, he takes up Young's Night-Thoughts, becomes melancholy, probably because of his abortive novel? Not at all; these are moral sensibilities, lofty enthusiasms! They ravage his head and heart; the man must find a breathing space. He takes up his pen; and the ill-conceived creatures flow in torrents into his pen. ... And this is the way his sensibilities are born, and nobody will ever dream that they are the afterbirth of an abortive novel. ${ }^{27}$

This satirical description of a bogged-down novelist who faute de mieux imitates Young, is of general interest over and above its specific theme. Such wallowing in songs of night and death after the pattern of the Night-Thoughts or graveyard literature modelled on Gray, or the feverish enthusiasm for Ossian that overran Germany like an epidemic - all this in fact conforms in one respect to the path the German novel was to take - namely, to the increasing unfolding of themes of selfscrutiny, self-analysis, self-experience, self-involution and selfdevelopment. In Germany, English impulses are channelled into that labyrinth of subjectivity, to whose twisting paths the authors painfully submitted themselves. 
Such a spirited book as the Sentimental Journey acted like a narcotic on the German public, and, as a contemporary has it, caused the spread of a 'general wasting sickness of the emotions. ${ }^{28}$ Shivers of emotion were felt in books and in everyday life. In the majority of Sterne's imitators there is hardly a trace of his delicacy of perception and attendant ironic treatment of what is felt. Perhaps more than anywhere else his spirit can be sensed in Georg Christoph Lichtenberg's aphorisms and letters. For the rest, Yorick released a truly excessive excrescence of inner life in Germany. Goethe, in his Campagne in Frankreich (Campaign in France), gave this perspicacious judgement: 'Even if his (Yorick's) spirit did not hover over the Germans, his sensibility could be felt all the more. A kind of tenderly passionate asceticism emerged, which usually degenerates into tiresome self-torment, since we were not endowed with the humorous irony of the Briton. ${ }^{29}$ There is no doubt that one of Goethe's works Die Leiden des jungen Werthers (The Sorrows of Young Werther) is a prime example of this type of 'selftorment.' Even though this torment cannot be ascribed to the same extent to novels ranging from Wieland to Jean Paul, their abiding characteristic is the preoccupation with the self. ${ }^{30}$ It is exclusively the inner history, the presentation of the inner world that the German writer tried to create. The wealth of material, experiences and observations culled from English novels and introduced into German ones, merely serves to liberate the power of imagination, which, in all its eccentric excursions to the outer world, reflects inner processes.

Elements of form and content from English novels recast in German novels led to the development of the self, and, at the same time, often culminated in vaguely perceived expansions of consciousness and experience, in the removal of all confines and, ultimately, in a state of 'Weltlosigkeit', complete inwardness. At the same time, it was realized at an early stage that something was missing and that a palliative was needed. This is the only way to explain the success of a book like Goldsmith's Vicar of Wakefield in Germany. In the Friederike episode of Dichtung und Wahrheit (Poetry and Truth), Goethe remodelled its intimate domesticity to describe family life at the Sesenheim vicarage. And even Lotte in Werther declares her love for this book by saying: 'The dearest author to me is that one, in whose work I recognize my own world, where things happen as they happen to me, and whose story I find as interesting and as loving as my own home life which is certainly not paradise, but on the whole a source of unspeakable happiness. ${ }^{31}$ Goldsmith conveyed a spirit of limited domesticity that appears again, somewhat programmatically, in Voss's Luise and Goethe's Hermann und Dorothea. In Jung-Stilling's Jugend (Youth), a 'true story' of 1777, it developed into a forerunner of the nineteenth-century country tale. 
But these literary phenomena dealing with limited middle-class life are demonstrably counter-responses, secondary reactive responses to the dominance of the growing narrative imagination, which roams unfettered in all directions. The new reader, who is now alone, reading silently to himself, is exposed to all this and it makes him uneasy - it urges him on to uncontrollable and insatiable desires. In the course of the century, the principle of removing boundaries prevailed in every literary genre according to the type, and produced an increasingly exclusionary power in man that no longer reproduced nature by imitation, but spontaneously invented a whole, which is 'coherent and proportioned in itself, with due subjection and subordinacy of constituent parts.' In the latter context, there is no doubt that Shaftesbury exerted enormous influence on German intellectual life. Now the holder of this power, 'a second maker, a just Prometheus under Jove, ${ }^{32}$ no longer imitates what is made, but the act of making - not the creation, but the creator; he becomes 'creative.' (The eighteenth century, by the way, still sensed the boldness, not to mention the blasphemy in identifying a human activity in this way. ${ }^{33}$

The fact that this view of the genius gradually won out and gave the development of German literature its own particular character is due, in fact, not so much to theory as to example: the overpowering appearance of an English writer who divided German opinion. How is it that Shakespeare (the writer I am referring to, of course) came into view in the eighteenth century? How is it that the Germans discovered Shakespeare in the Enlightenment - I repeat, in the Enlightenment and not counter to the Enlightenment? At first, at the beginning of the century, his name is hardly known, and the scanty information that trickles through generally comes from French sources, usually through Holland. What comes into Germany in this manner, above all by way of the Spectateur, the French translation of the Spectator that appeared in Amsterdam in 1714-1726, is a picture already containing the basic material to ignite the vehement controversy between those who support Shakespeare and those who do not. Shakespeare appears here as a 'genius of the first order, who owes his great art to his natural talent alone and who creates his tragedies and comedies without the organizing influence of rules. ${ }^{34}$ The two poles stressed here are: natural genius on one hand and, on the other, no rules. The way in which Shakespeare is at first received and judged follows the paths suggested here. Johann Elias Schlegel, in his essay Vergleich Shakspeares und Andreas Gryphs (Shakespeare and Andreas Gryphius Compared) of 1741 sees Shakespeare's strength in his characterizations, in his deep understanding of human nature, and he sees his weaknesses, apart from bombastic images, in his defective organization, his ignoring of the unities. ${ }^{35}$ This corresponds to what 
Gottsched said in 1732 about English dramatists in general: 'The English are indeed fortunate in their thoughts and expressions, they formulate good characters and know how to imitate the manners of men very well, but as far as the organization of the plot is concerned, they are not masters. ${ }^{36}$

Now of course, works by Shakespeare himself were not really accessible to the German public; apart from a 1741 translation of Julius Caesar in alexandrines, ${ }^{37}$ most of what was known at the time came from a complete translation of the English Spectator, the Zuschauer, of 1739-1740, in which the first published translations of Shakespearean blank verse also appeared. These verses, which are only slightly inferior to the translation by August Wilhelm Schlegel, were written by Gottsched's wife. ${ }^{38}$ Of course, it was just at this time that her husband was embarking on his unfortunate literary feud with the Swiss, and the hardening of his attitude drove him to such violent polemic - also in judging Shakespeare - that even today, literary criticism has a hard time doing him justice. There is only one positive aspect to his onesidedness: it clarifies positions. Rules and genius, art and nature move further and further apart; it is by way of these opposing tensions dominating the Enlightenment that Shakespeare enters the intellectual and literary history of Germany.

The voices of Shakespeare's admirers multiply noticeably in the 1740s and 1750s, but they do not yet challenge the principle of rules to any great extent. From the point of view of rules, the idea that there could even be such a thing as an 'unregulated genius' must seem highly paradoxical. For if there really are recognizable and nameable standards of literary art-criteria by which the aesthetic value of a work can be determined unequivocally - then every conceivable feature of a literary work can be identified only within these norms; beyond them, nothing is of value. Those who advocated rules and, at the same time, acknowledged Shakespeare's greatness, therefore logically found themselves in something of a predicament which Lessing brashly dismissed in his seventeenth Literaturbrief (Literary Letter) where he concluded that 'even according to the ancient model,' Shakespeare was 'a greater tragic poet than Corneille. ${ }^{39}$ This was a contention he did not (and could not) prove. No, the circle cannot be squared. Shakespeare, instead, was an obstacle to normative poetics, and it should be noted that the Enlightenment took this up in a productive way. Loyalty to principles did not win out.

Yet the fact that the phenomenon of Shakespeare overcame the principle of rules was connected with a change in the concept of nature which had been underway for some time. Using the Spectator ${ }^{40}$ as a model, Möser compared the natural genius with the thickets, grottos, ruins and woods of an English garden. ${ }^{41}$ (Shaftesbury had already written that 'the wildness pleases.' $)^{42}$ Möser continued to say that the 
natural genius need abide not by rules, but by nature and the dynamic, spontaneous forces within himself. Old Edward Young had something important to say on this matter - at least, so it seemed to the Germans. For in his Conjectures on Original Composition of 1759, where he discusses the age-old question of whether the 'Anciens' or 'Modernes' should have precedence, he comes down against imitating the authors of antiquity, and reserves the word 'original' for the imitation of nature. This was in fact nothing particularly new; but the clever, pointed way in which he presented his arguments was appropriate for making an impact in Germany, where the term 'original genius' was then defined a little more vigorously than Young had in fact intended. When we read such lines as: 'Rules, like crutches, a needful aid to the lame, tho' an Impediment to the strong. A Homer casts them away, ${ }^{43}$ we can grasp the misunderstanding as well as the fascination of his essay as reflected in Herder's enthusiastic statement: 'Why do we feel a certain fire starting to glow when we read Young's On Originals, a fire we do not feel when we just read basic analyses: because Young's spirit dominates there, speaks from heart to heart, from genius to genius, it conveys itself like an electric spark. ${ }^{44}$ In using the notion of this electric transmission from genius to genius, Herder furthers Lessing's idea that 'a genius can be ignited only by a genius,' which he used to recommend Shakespeare as a model for the Germans. ${ }^{45}$ Thus, Herder, as a result of Young's influence, thoroughly rejects the concept of transmission by imitation when he says: 'The spirit of a nation is never changed by detailed speculations, but always by great examples. ${ }^{46}$

When Herder wrote these words, the 'great example' of Shakespeare, who until that time had only been quoted and discussed by literary experts, was finally available to Germans in German: in the Wieland translation of 1762-1766. To keep things in proportion, it must be stressed that however important Lessing was for propagating Shakespeare in Germany - which he did not so much because of any new revelations, but because of the liveliness of his pointed polemics and by dint of his authority - the decisive and truly epoch-making work for our literature was Wieland's translation of 22 Shakespeare plays. The result was that an author who had already been widely discussed, but who was himself hardly known, finally became readily accessible to the German public. This achievement cannot be overestimated. So eighteenth-century Germans knew Shakespeare through Wieland's translation. (Goethe, by the way, preferred it all his life.) Wieland had to pick out his knowledge of English from inadequate dictionaries - he had practically no predecessors at all! One might have assumed that such a pioneer work would have received due recognition, and that especially those who were always talking about Shakespeare as their model would 
have appreciated the translator who made their idol available in German. But no - the opposite occurred. The translation was of course widely read - it was 'devoured' (as Goethe attests), it 'spread quickly and had a great effect. ${ }^{, 47}$ (Wilhelm Meister in Goethe's novel, for example, reads Shakespeare, who makes a powerful impression on him and changes his life - he, of course, read it in the Wieland translation. ${ }^{48}$ But in public statements, Wieland and his work were greeted almost exclusively with ingratitude and censure, if not with the most impassioned invective.

Of course, there were reasons for this ingratitude. These are to be found not so much in the numerous translation errors which were unavoidable under the circumstances, nor in the prose form chosen by Wieland (with the exception of A Midsummer Night's Dream), since those of the Sturm und Drang who used his translation in their own Shakespearean efforts also used prose. The reasons were rather to be found in Wieland's understanding of Shakespeare which was reflected, among other things, in critical notations by the translator. Compared with the attitudes of younger contemporaries, this was very old-fashioned indeed. Nevertheless, Wieland's understanding of Shakespeare was as enthusiastic as that of the Sturm und Drang; Shakespeare, says Wieland, is the prime dramatist of every age and every country.... Someone who speaks of the signs of great genius often to be found in his works arouses the suspicion that he has never read them. It is not signs, but the perpetual radiation and complete outpouring of the most powerful, the richest and the most sublime genius ever to stimulate a poet, that overpower me when I read his works - that render me insensitive to his mistakes and irregularities. ${ }^{49}$ Yet precisely the last words, 'mistakes,' 'irregularities,' show that Wieland was still clinging to such things as 'rules,' such things as norms of correctness.

This is exactly what younger contemporaries were no longer willing to accept. Their enthusiasm for Shakespeare is accompanied by the vehement rejection of what went before, especially the immediate past and its older generation. Yet at the same time, the transition from the Enlightenment is actually smooth. Heinrich Wilhelm von Gerstenberg, who was still basically bound to Anacreontic tastes and bardic poetry, angrily picked holes in Wieland's Shakespeare translation in his Briefe über Merkwürdigkeiten der Literatur (Letters on Literary Curiosities) of 1766. But in his discussion of Shakespeare, he paved the way for the new ideas in a remarkable manner. First of all he rejects the legitimacy of genre in Shakespeare's case, that is to say, the distinction between tragedy and comedy, etc.: 'Away with the classification of drama. Call these plays what you will: I call them living pictures of moral nature. ${ }^{50}$ For Gerstenberg, however, the representation of this world, this 'moral nature,' is 
no longer a matter of someone of talent having studied nature and thus being in a position to reproduce faithfully and tastefully what he has seen. On the contrary, it is a matter of someone to whom nature speaks from inside himself, without reflection, without deliberation. The change, 'from nature as object, to nature as subject,', ${ }^{51}$ leads to a concept of genius which now has nothing to do with any particular human skill or ability. The 'poetic (that is to say, creative) genius' is separated from the 'bel esprit': 'Ben Jonson, Corneille, Virgil were great minds, wrote masterpieces, and had no genius. Shakespeare, a genius, seldom wrote masterpieces and was no bel esprit. ${ }^{52}$ A genius - and Shakespeare, says Gerstenberg, not only has genius, but is a genius - is not determined by the writing of 'masterpieces,' but is a form of creative being that previously could only be associated with the Creator himself. Gerstenberg writes that 'Shakespeare's genius' possessed all knowledge and all talent 'without any practice, as if by a kind of inspiration. ${ }^{53}$ The idea of divine inspiration rings loud and clear here, yet Gerstenberg distances himself from the religious connection.

Herder, ultimately, also bases his picture of Shakespeare on the religion-bound ideas of Hamann who was the first not to make excuses for the 'ignorance or violation' of poetic rules in Shakespeare, but saw it as an almost necessary part of his genius, since something divine in man spoke from him. ${ }^{54}$ And so for Herder, in his discussion of Shakespeare in Von deutscher Art und Kunst (On German Life and Art) of 1773, Shakespeare is a 'mortal with divine power. ${ }^{55}$ His plays are not finely crafted products, dramaturgically perfect, but

merely single leaves from the book of events, of Providence, of the world, blowing in the storm of time ... single impressions of peoples, classes, souls. . . . As in the hand of the Creator, we are all blind tools in the totality of one theatrical picture, of a great event which the poet alone can survey.... The scenes of nature approach and recede; they influence each other, however disparate they may seem; they generate each other and destroy each other, and in this way they fulfill the intention of the creator who seemed to have used a drunk and disorderly plan; they are dark little symbols forming a silhouette of a divine theodicy. ${ }^{56}$

Just as God created his works, so the poet created his: from this point of view, the unruly, enigmatic, incommensurable quality of Shakespeare's works is no longer denounced as an infringement of the rules, but is, on the contrary, a sign of the highest poetic power. The former understanding of the word 'poet' - that is to say, someone who skillfully arranges material, who is gifted with great powers of invention, powers of combination, and who can fashion the language to specific 
effect by means of his rhetorical skill - no longer applies. 'This is not a poet,' cries Herder, 'this is a creator, this is the history of the world! ${ }^{157}$

As a result of the exciting brilliance of this essay by Herder, where his sentences are often elliptical, but nevertheless powerfully energized by enthusiasm, a poetic concept of self sets in which was certainly not free of problems and dangers, especially for those of little or middling talent (who felt obliged to overestimate themselves quite strenuously). For our great men of literature, however, the concept of self released productive energies all the more. In Germany, Shakespeare had become a symbol and expression of nature and originality, which - at least briefly for a certain group - no longer merely strained against everything conscious and regulated, but opposed it. It may seem strange that in his collected folksongs, using Percy's Reliques of Ancient English Poetry as a model, Herder included excerpts from Shakespeare in his search for origins, which also induced his veneration for Ossian. Yet he could do this with a clear conscience, since originality for him was basically not an historical category dependant on any particular time or age, but a category of style. ${ }^{58}$ And at the end of his essay on Shakespeare, hope is infused into the course of history, which is allegedly becoming more and more sterile:

Happy am I that I lived at a time when I could understand him (Shakespeare) and when you , my friend - you who can recognize yourself and sense yourself when reading this, and whom I have embraced more than once before his holy picture - a time when you can still have the sweet dream you deserve of setting up his monument from our age of chivalry in our language, in our worn-out fatherland. I envy you the dream and your noble German work. Do not slacken until the wreath hangs high above. ${ }^{59}$

It is easy to guess who the friend is - Goethe. According to Herder, he was about to create in his Götz von Berlichingen an 'event of outand-out greatness, an occurrence of world significance, of human fate ${ }^{60}$ in the Shakespearean sense.

Goethe had first become acquainted with Shakespeare not in Strasbourg, but in Leipzig (essentially through Dodd's anthology, the Beauties of Shakespeare). ${ }^{61}$ But it is in Strasbourg that a true cult instigated by Herder begins, where Goethe participated in the Sturm und Drang enthusiasm for Shakespeare. His most well-known testimonial of this period is the Rede zum Schäkespears Tag (Speech on the Occasion of Shakespeare's Commemoration), which was read out to a small group in 1771 in honour of the writer and which has been preserved by chance. The speech was modelled on Shakespeare celebrations at Stratford in 1769 run by Garrick. ${ }^{62}$ It is more of a passionate outpouring than a systematic 
essay and bears the stamp of ideas conveyed by Herder. But the concept of nature ('Nothing is as much nature as Shakespeare's characters'), and the concept of freely unfolding the power of imagination which sees the unities and all the rules as prison walls and fetters; the characterization of Shakespearean theatre as a beautiful cabinet of curiosities in which the history of the world rages past before our eyes on the invisible thread of time,' where there is no dramatic collision of freedom and necessity determined by a philosopher; to all of this Goethe adds something more: his quiet but still clearly audible confidence in being able to follow in the footsteps of the giant: 'looking at a single footstep makes our souls greater and more ardent... We have within ourselves the germ of those merits we treasure. ${ }^{63}$ Therefore, it is not surprising that Goethe assimilated Shakespeare most creatively in his own literary work. The rhapsodic tribute in his Shakespeare Commemoration is simply a preamble to a life's work into which the shape of Shakespeare's universe infused streams of productivity. Yet this goes beyond any verifiable influence. It would of course be possible to give a great deal of concrete evidence, for instance, the arrangement and denseness of the scenes in Götz or many passages in Wilhelm Meisters Lehrjahre (Wilhelm Meister's Apprenticeship). But this latter work, the unsuccessful theatrical mission of the hero, called 'William' after his idol, as well as his education which is strangely and paradoxically reflected in the Hamlet episodes, are clearly not everything; they are possibly not even the essence. One feels that the infinitely, intricately interwoven whole of the novel could not have come into being without the experience of the world in Shakespeare's work. Once, probably in his Weimar period, Goethe personified and celebrated the two great powers that determined his existence - in his old age, he called them 'idea and love': ${ }^{64}$

Lida! Glück der nächsten Nähe,

William! Stern der schönsten Höhe,

Euch verdank ich, was ich bin. ${ }^{65}$

It is to Lida (Charlotte von Stein) and William (Shakespeare) that he owes what he is.

Looking back now from the end of this all too cursory sketch - not the end of the topic, of course - we can see the way in which English literature was taken up and transmuted in eighteenth-century Germany; we can see the remarkable path taken by German literature, from the flourishing moral weeklies at the beginning of the century, to the life and work of Goethe. Of course, English literature was not the only influence on eighteenth-century Germany; other European literatures, especially French, are also very important. But it is certainly true that without the 
confrontation with English literature, German literature would have taken a different, and probably far more modest course. Eighteenth-century English literature binds, separates and releases extraordinary forces in Germany. During his stay in England, Lichtenberg noted: 'I really went to England to learn how to write German. ${ }^{166}$ Changing this sentence slightly, we can say: German writers of the eighteenth century turned to English books to learn how to write German.

\section{PETER MICHELSEN \\ University of Heidelberg \\ Translated by Elizabeth Spence}

\section{Notes}

1 This paper is an abbreviated translation of my German essay 'Entgrenzung: Die englische Literatur im Spiegel der deutschen im 18. Jahrhundert,' which is shortly to appear in the book Der unruhige Bürger: Studien zu Lessing und zur Literatur des 18. Jahrhunderts.

2 J.C. Gottsched, letter of May, 1739, quoted in Johann Christoph Gottsched und die Schweizer J.J. Bodmer und J.J. Breitinger, ed. Johannes Crüger. Deutsche National-Litteratur. ed. Jos. Kürschner, vol. 42 (Berlin/Stuttgart, n.d.), introduction, p. lix.

3 In the preface to the first edition of the drama of 1732. Reprinted in Johann Christoph Gottsched: Ausgewählte Werke, ed. Joachim Birke, II, (Berlin, 1970), p. 10.

4 Friedrich von Hagedorn, Moralische Gedichte (Hamburg. 1750), p. 15.

5 In 'Das Neueste aus dem Reiche des Witzes' ('The Latest from the Realm of Wit'), supplement to the Berlinische privilegierte Staats- und gelehrte Zeitung (the Vossische Zeitung), May, 1751, p. 45.

6 In Die unüberwindliche Flotte, Nationalausgabe, I, p. 173.

7 Friedrich Nicolai, Briefe über den itzigen Zustand der schönen Wissenschaften in Deutschland (Berlin, 1766), p. 113.

8 Wolfgang Martens, Die Botschaft der Tugend: Die Aufklärung im Spiegel der deutschen Moralischen Wochenschriften (Stuttgart, 1968), pp. 544-48, 550-52.

9 Martens, p. 24.

10 Die Discourse der Mahlern, Erster Theil (Zurich, 1721), dedication, n.p.

11 See J.C. Gottsched, Beytr. zur Crit. Historie der Deutschen Sprache, Poesie und Beredsamkeit, II,1 (Leipzig, 1732), in which he says that Milton's 'famous poem' had 'earned the honour of being placed side by side with the Iliad and the Aenead as well as Tasso's Jerusalem Delivered' (p.85). Elsewhere in the Beyträge he writes that Bodmer 'has brought out such strength in our language, that one could say that 
through this translation Millton (sic) has acquired more force and energy than he has in his mother tongue.'

12 This typical formulation is by Hermann Hettner, Geschichte der deutschen Literatur im 18. Jahrhundert, ed. Georg Witkowski, I (Leipzig, 1928) p. 211.

13 This is already to be found in the early, still quite friendly correspondence between Gottsched and Bodmer. On October 7, 1732 Gottsched wrote: 'I admit that I am anxious to know the rules by which such an unregulated power of imagination as Milton's can be excused' (Crüger, p. lvii).

14 J.J. Bodmer, Critische Abhandlung von dem Wunderbaren in der Poesie und dessen Verbindung mit dem Wahrscheinlichen. In einer Vertheidigung des Gedichtes Joh. Miltons von dem verlohrnen Paradiese; Der beygefuget ist Joseph Addisons Abhandlung von den Schönheiten in demselben Gedichte (Zurich, 1740), p.21.

15 Beyträge, VI,24 (1740), p. 664f.

16 Abhandlung von der Schreibart in Miltons verlohrnem Paradiese (1740), in Karl Ludwig Schneider, Klopstock und die Erneuerung der deutschen Dichtersprache im 18. Jahrhundert, Probleme der Dichtung, 8 (Heidelberg, 1965), p. 16.

17 This expression ('herzrührende Schreibart') was coined by Breitinger who devoted a whole section to it in his Fortsetzung der Critischen Dichtkunst ... , Sec. 8 (Zurich, 1740), p. 352ff. See also Schneider, p. 20.

18 Letter to Bodmer of 10.8.1748, in F.G. Klopstock, Sämmtliche Werke, X (Leipzig, 1844), p. 361.

19 Beyträge. I,1 (1732), p. 90.

20 Die Räuber. I,2 (suppressed sheet B). Nationalausgabe, III, p. 248.

21 See Horst Oppel, Englisch-deutsche Literaturbeziehungen, I, Grundlagen der Anglistik und Amerikanistik, 1 (Berlin, 1971), p. 127.

22 F.G. Klopstock, 'Die todte Clarissa,' Sämmtliche Werke, IV (Leipzig, 1854), p. 68f.

23 C.F. Gellert, epigram 'Unter Richardsons Bildniss' ('Under Richardson's Likeness'), in Almanach der deutschen Musen auf das Jahr 1771 (Leipzig, 1771), p. 97.

24 See H. Petriconi, Die verführte Unschuld: Bemerkungen über ein literarisches Thema. Hamburger romanistische Studien, 38 (Hamburg, 1953), p. 100.

25 Petriconi, p. 110.

26 L.M. Price, Die Aufnahme englischer Literatur in Deutschland (1961).

27 Briefe, die Neueste Litteratur betreffend, Part XIX (Berlin, 1764), 159-63. The author of this letter signed himself ' $Q$ '. According to Nicolai's letter to Herder of 24.12.1768 he was Friedrich Gabriel Resewitz (1729-1806). See also Price, p. 189.

28 C.E.F. Schulz, Litterarische Reise durch Deutschland, II (Leipzig, 1786), p. 34.

29 J.W.Goethe, Campagne in Frankreich, Jubiläumsausgabe, XXVIII, p. 164.

30 See my book Laurence Sterne und der deutsche Roman des 18. Jahrhunderts, 2nd ed. Palaestra, 232 (Göttingen, 1972).

31 J.W. Goethe, Die Leiden des jungen Werthers, Book I, June 16th, Jubiläumsausgabe, XXVI, p. 22f. 
32 Anthony, Earl of Shaftesbury, Soliloquy or Advice to an Author, I,3; in Characteristics of Men, Manners, Opinions, Times, ed. John M. Robertson, I (Indianapolis/New York, 1964), p. 136.

33 In 1751 in the supplement to the Vossische Zeitung (p.40f.) Lessing cites Daniel Wilhelm Triller (1695-1782) as follows: 'Writing creatively, making verses creatively are punishable and unchristian expressions.... We know from the scriptures, reason and nature that there is only one single creator.... The philosophers, even the theologians themselves, should have thought twice before they dedicated the dignity of creator to a powerless creature.'

34 Kurt Schreinert, Der Spectateur und sein Shakespeare-Bild 1714-26. Zugleich ein Beitrag zur kontinentalen Frühgeschichte der moralischen Wochenschriften, Shakespeare Studien. Festschrift für Heinrich Mutschmann, eds. Walther Fischer and Karl Wentersdorf (Marburg, 1951), p. 145.

35 In Gottsched's Beyträge, VII, 28 (1741), 540-72.

36 J.C. Gottsched, preface to Der sterbende Cato, in Ausgewählte Werke, p. 13.

37 The translator was the Pommeranian Casper Wilhelm von Borcke (not 'Borck' as is given in almost all sources) who spent several years in England. From 1726 to 1728 he was attaché at the Prussian embassy there.

38 See my review of Price in Die Göttingischen Gelehrten Anzeigen, 20 (1968), 239-282. Apart from Schreinert, critics have ignored Frau Gottsched's translation. It is important that literary critics not view Frau Gottsched in the shadow of her husband, as is generally the case. Th. W. Danzel suggested that her alienation from her husband in the last years of her life was probably not only due to personal tensions, but also to differences of opinion on literary questions. 'I do not think I am overstating the case when I say that these experiences (literary differences) broke her heart, that she in fact died of them.' (Th. W. Danzel, Gottsched und seine Zeit, 2nd ed. [Leipzig, 1855], p. 183f.).

39 G.E. Lessing, Werke, IV, p. 57

40 Spectator, Sept. 3, 1771, No. 160 (by Addison).

41 Justus Möser, Über die deutsche Sprache und Litteratur (1781) in Sämmtliche Werke ed. B.R. Abeken, 2nd ed, X (Berlin, 1858), p. 146.

42 Earl of Shaftesbury, The Moralist: A Philosophical Rhapsody, in Robertson (ed.) Characteristics, II p. 122.

43 Edward Young, The Works: A New Edition, V (London, 1773), p. 98.

44 J.G. Herder, Introduction to Über die neuere deutsche Literatur: Zweite Sammlung von Fragmenten (1767), in Werke, ed. Ernst Naumann, I (Berlin/Leipzig/Wien, Stuttgart, n.d.), p. $105 \mathrm{f}$.

45 Lessing, Werke, p. 57.

46 Herder, Werke, p. 106.

47 Goethe, Dichtung und Wahrheit, III, 11, Jubiläumsausgabe, XXIV, p. 56.

48 Goethe, Wilhelm Meisters Lehrjahre, V, 5, in Jubiläumsausgabe, XVIII, p. 23.

49 C.M. Wieland, Sämmtliche Werke, 44 (Leipzig, 1827), pp. 158-60. 
50 H.W. von Gerstenberg, Briefe über Merkwürdigkeiten der Litteratur, 14th letter, rpt in: Deutsche Litteraturdenkmale des 18. und 19. Jahrhunderts, 29/30, ed. Alexander von Weilen (Stuttgart, 1890), p. 112f.

51 Klaus Gerth, Studien zu Gerstenbergs Poetik, Palaestra, 321 (Göttingen, 1960), p. 46.

52 Gerstenberg, Briefe, 20th letter, pp. 215, 216.

53 Gerstenberg, Briefe, p. 219.

54 J.G. Hamann, Sämtliche Werke, ed. Josef Nadler, II (Wien, 1950), p. 75.

55 Herder, Werke, II, p. 224.

56 Ibid, pp. 225f.

57 Ibid, p. 228.

58 See my essay 'Regeln für Genies. Zu Herders Fragmenten 'Über die neuere deutsche Litteratur" which is to appear shortly.

59 Herder, Werke, II, p. 235.

$60 \mathrm{Ibid}, \mathrm{p} .234$.

61 Goethe, Dichtung und Wahrheit, III, 11, Jubiläumsausgabe, XXIV, p. 55.

62 See Ernst Beutler, 'Goethe und Shakespeare,' in Goethe, Rede zum Schäkespears Tag. Wiedergabe der Handschrift, Schriften der Goethe-Gesellschaft, 50 (Weimar, 1938), pp. $14 \mathrm{ff}$.

63 Goethe, Rede. Jubiläumsausgabe, XXXVI, pp. $3 f$.

64 Goethe, 'Buch der Betrachtungen,' West-östlicher Divan, Jubiläumsausgabe, V, p. 39.

65 Goethe, Jubiläumsausgabe, II, p. 219.

66 Lichtenberg in England: Dokumente einer Begegnung, ed. Hans Ludwig Gumbert, I (Wiesbaden, 1977) p. 247 (E 144). 